\title{
Inside the 'Hurt Locker': the combined effects of explosive ordnance disposal and chemical protective clothing on physiological tolerance time in extreme environments
}

\author{
Joseph T Costello ${ }^{1,2^{*}}$, Kelly L Stewart ${ }^{2}$, lan B Stewart ${ }^{2}$ \\ From 15th International Conference on Environmental Ergonomics (ICEE XV) \\ Portsmouth, UK. 28 June - 3 July 2015
}

\section{Introduction}

Explosive ordinance disposal (EOD) technicians are often required to wear specialised clothing combinations that not only protect against the risk of explosion but also potential chemical contamination. This heavy $(>35 \mathrm{~kg})$ and encapsulating ensemble is likely to increase physiological strain by increasing metabolic heat production and impairing heat dissipation $[1,2]$. This study investigated the physiological tolerance times of two different chemical protective undergarments ( $2.9 \mathrm{~kg}$ v's $4.2 \mathrm{~kg}$ ), commonly worn with EOD personal protective clothing, in a range of simulated environmental extremes and work intensities.

\section{Methods}

Seven males performed eighteen trials wearing two ensembles. The trials involved walking on a treadmill at $2.5,4$ and $5.5 \mathrm{~km} \cdot \mathrm{h}^{-1}$ at each of the following environmental conditions, $21{ }^{\circ} \mathrm{C}, 30^{\circ} \mathrm{C}$ and $37{ }^{\circ} \mathrm{C}$ wet bulb globe temperature (WBGT). The trials were ceased if the participants' gastrointestinal temperature reached $39{ }^{\circ} \mathrm{C}$, if heart rate exceeded $90 \%$ of maximum, if walking time reached 60 minutes or due to volitional fatigue.

\section{Results}

Physiological tolerance times ranged from 8 to $60 \mathrm{~min}$ and the duration (Figure 1, mean difference: $2.78 \mathrm{~min}$,
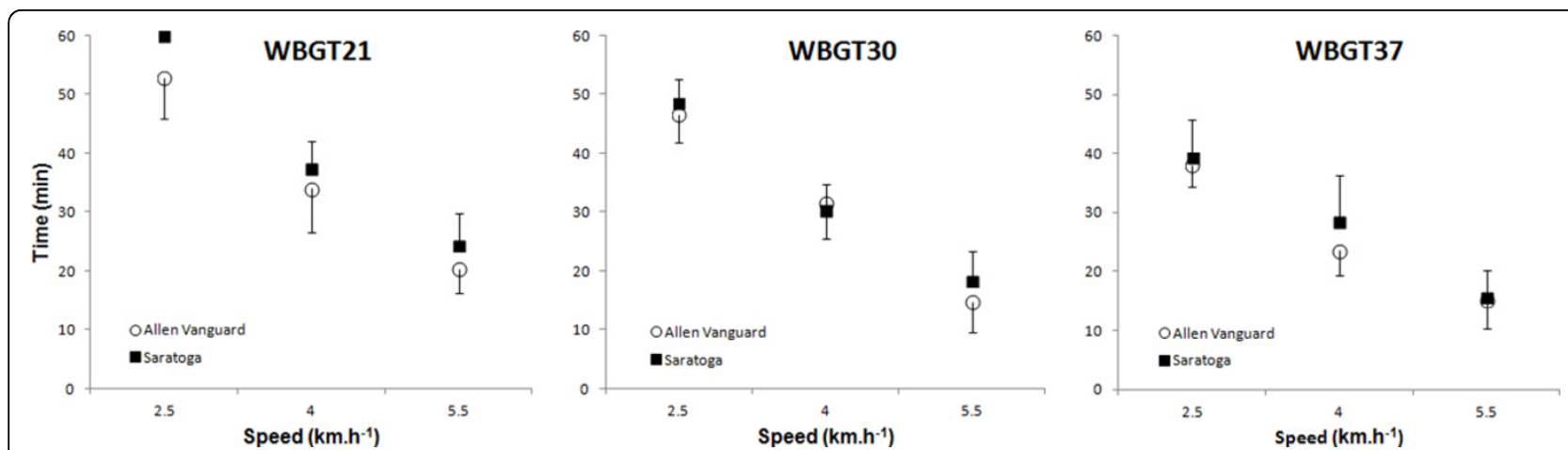

Figure 1 Tolerance time (mean \pm SD) in both ensembles across the different environmental conditions and work rates.

\footnotetext{
* Correspondence: joe.costello@port.ac.uk

${ }^{1}$ Extreme Environments Laboratory, Department of Sport and Exercise

Science, University of Portsmouth, Portsmouth, UK

Full list of author information is available at the end of the article
} 
$\mathrm{P}>0.05)$ were similar in both ensembles. A significant effect for environment $\left(21>30>37^{\circ} \mathrm{C}\right.$ WBGT, $\left.\mathrm{P}<0.05\right)$ and work intensity $\left(2.5>4>5.5 \mathrm{~km} \cdot \mathrm{h}^{-1}, \mathrm{P}<0.05\right)$ was observed in tolerance time. The majority of trials across both ensembles $(101 / 126 ; 80.1 \%)$ were terminated due to participants achieving a heart rate equivalent to greater than $90 \%$ of their maximum.

\section{Discussion and conclusion}

This is the first study to systematically compare the physiological tolerance times of two air-permeable, charcoal-impregnated chemical protective undergarments while worn in combination with EOD personal protective clothing. Physiological tolerance times wearing these two ensembles were similar and predominantly limited by cardiovascular strain.

\section{Authors' details}

${ }^{1}$ Extreme Environments Laboratory, Department of Sport and Exercise Science, University of Portsmouth, Portsmouth, UK. ${ }^{2}$ School of Exercise and Nutrition Sciences and Institute of Health and Biomedical Innovation, Kelvin Grove, Queensland University of Technology, QLD 4059, Australia.

Published: 14 September 2015

\section{References}

1. Stewart IB, Stewart KB, Worringham CJ, Costello JT: Physiological tolerance times while wearing explosive ordnance disposal protective clothing in simulated environmental extremes. PLOS ONE 2014, 9(2):e83740, doi:10.1371/journal.pone.0083740.

2. Stewart IB, Townshend A, Rojek A, Costello JT: Bomb Disposal in the Tropics: A cocktail of Metabolic and Environmental Heat. Journal of Ergonomics 2013, S:2[http://dx.doi.org/10.4172/2165-7556.S2-001].

\section{doi:10.1186/2046-7648-4-S1-A79}

Cite this article as: Costello et al:: Inside the 'Hurt Locker': the combined effects of explosive ordnance disposal and chemical protective clothing on physiological tolerance time in extreme environments. Extreme Physiology \& Medicine 2015 4(Suppl 1):A79.

\section{Submit your next manuscript to BioMed Central} and take full advantage of:

- Convenient online submission

- Thorough peer review

- No space constraints or color figure charges

- Immediate publication on acceptance

- Inclusion in PubMed, CAS, Scopus and Google Scholar

- Research which is freely available for redistribution

Submit your manuscript at www.biomedcentral.com/submit 